\title{
The Use of Academic Assessment Instruments For Students With Intellectual Disability in Special Schools
}

\author{
${ }^{1 *}$ Fauzi Nahwah Mujahid, ${ }^{2}$ Sri Yamtinah, ${ }^{3}$ Muhammad Akhyar \\ ${ }^{1,2,3}$ Special Education, Universitas Sebelas Maret, Surakarta, Indonesia
}

\begin{abstract}
The concept of assessment for students with special need exists is to find and gather information on the children's obstacles and potentials. In the implementation of special education assessment, it is a need to understand the various aspects of assessing the ability of the child. The aim of this research is to analyze the use of assessment for students with special need in Surakarta city. This research uses a qualitative approach to the subject of as many as 50 teachers from 11 inclusion schools and special schools. The result of this research shows that $82 \%$ inclusive and special schools in Surakarta city do not have a proper standardization in the use of academic assessment instruments by teachers at the beginning of the learning process yet. Moreover, $55 \%$ of schools do not do an initial assessment and do only the assessment at mid and end time of the learning process. The impact of the problems, when teachers do the assessment, bring through the results of the assessment to not cover the skills that will be assessed by the teacher.
\end{abstract}

Keywords: Instrument, Assessment, Students with Special Need

\section{Research Background}

In this era, education has a particular meaning as a learning process that is designed exclusively to meet the unique needs of people with disabilities. When a student was identified experiencing obstacles in learning, an extraordinary education is needed if the student is not able to be accommodated with the usual learning process. The student probably needs a media or learning strategy that is designed to accommodate learning individually.

One unique type of disabled children is a student with intellectual disorder which is known as general learning disability and mental retardation. Student with intellectual disorder according to American Association on Mental Deficiency define general learning disability and mental retardation as an abnormality that includes general intellectual functions below the average (sub-average), which IQ up to 84 , that appears before the age of 16 and shows detention in adaptive behavior (Kosasih,
2012). According to Kemis et al (2013) learning process for students with intellectual disorder these days are more classical, and learning process solely based on curriculum achievement. By this situation, education achievement becomes invaluable by the student, even the teacher does not see abilities and problems faced by students and only sees the learning outcomes. This problem should be overcome, because it is a teacher's fundamental thing in examining the students' abilities.

The student with intellectual disorder will gain their optimal result if their teachers are able to understand the disabled children character before they developing the school learning. Teachers must have and comprehend the knowledge about services and needs of children with disabilities, which are specific and general characteristic knowledge. General characteristic knowledge is the science of such the superiority that is owned by the disabled children. Meanwhile, specific characteristic 
knowledge is the data which be possessed by every student in a class. Those data can be obtained by the teacher from their own identification or accepted from the other professional identifiers. This particular knowledge is as important as the general knowledge because a kid whose known as disabled kid usually have a half of general characteristic so as the teacher get information and identify obstacles that they are facing.

The identification can be done by all people around the student environment without any certain procedure. Identifying students' problem is is the first step to recognize and identify problem happened to the student. In the specific education concept, according to Alimin (2002) teacher have to see the children needs from the very wide spectrum, which every kid has their special and unique needs. The identification process done simply and aims to identify students' abilities whether they need the service and education specifically or not.

After the identification process teacher do the next step, which is assessment for excavating the students' potency and obstacles for certain objective, it may for development or academic goal. The identification process and assessment are mutually sustainable and related to the objective and different process, but the assessment process is more complex.

Assessment is one of the efforts of teachers to see the fundamental problems faced by students with intellectual impairments. Assessment is a process to obtain information on student development before the learning process or during the learning process as a material for consideration in making teacher decisions to find out and compile student learning programs, both for learning plans or improvements to ongoing learning programs. Assessment shows students' abilities, both potential and actual obstacles. In addition, the teacher reflects an understanding of the development and progress of the student learning process.
Research conducted by Syamsi (2016) suggests that teachers in academic assessment require understanding and perseverance, teachers are also required to more closely observe all activities related to the assessment objectives.

Many conceptual and technical issues in preparing assessment instruments can assess whether the assessment information obtained is accurate, reliable, and valid. According to Salvia \& Ysseldyke (Thurlow, 1998) assessment refers to data collection. Data can be collected in various ways, one of which is testing. Most people think of testing when they think of judgment, but assessment also includes gathering, to measure an ability through questions.

Assessment is an integral part of instruction, because through the assessment process can determine the learning program needs that students will pass. The development of assessment instruments, according to Hussu \& Strle (2010) places teacher experience that is very important in understanding characteristics, developing adaptation and modification according to children's needs, and working in teams with practitioners and specialists of children with special needs. Assessment influences decisions about value, placement, progress, instructional needs, and curriculum. The main objective of the assessment, according to Witt et al (1998) is to gather information to facilitate effective decision making. In education, assessment is used to help teachers, administrators, psychologists, parents and students. There are at least five types of decisions for the purpose of assessment: screening, classification and placement, student progress, programs or teaching, and program effectiveness decisions (Ysseldyke, 1979; Witt et al, 1998).

The assessment process in assessment is very complex and special education conceptually and technically continues to grow rapidly, making the development of assessment instruments for children with special needs continue to evolve and vary in 
terms of assessment, techniques and purpose of use. So that it is necessary to make an effort to develop assessment instruments that are accurate, reliable and validated by experts. This effort is a renewal of the assessment in the assessment instrument.

The purpose of this study was to find out how the use and process of academic assessment instruments have been applied by classroom teachers in special schools and inclusion in Surakarta City. In addition, it is hoped that this research can provide information about the problem of using assessment instruments for children with special needs, especially children with intellectual disabilities.

\section{Method}

This study uses descriptive research methods with quantitative approaches. The subjects were taken as many as 50 teachers from 11 special schools and inclusive public schools spread in the city of Surakarta. Data collection techniques with interview techniques to take as much data as possible about the problems that occur in teachers who conduct assessments in children with intellectual impairments. Data analysis using data analysis techniques using descriptive quantitative analysis by analyzing a lot of data and then classifying and interpreting into the form of images and graphics and descriptive to conclude.

\section{Results}

Academic assessment is a part of assessment that is made to measure the initial ability in seeking information on obstacles and academic potential of students with intellectual impairments before being placed or diagnostic. In addition, assessment helps students with intellectual disabilities in the learning process to understand how students learn, what obstacles they face and how the teacher overcomes these obstacles.

The use of good and appropriate assessment instruments can make it easier for teachers to explore information about students. A good and precise instrument measures students' abilities based on indicators that are a reference in implementing interventions. If the teacher is unable to understand the aspects to be measured, the teacher cannot understand the abilities students should master.

\section{The use of initial academic assessment Instruments}

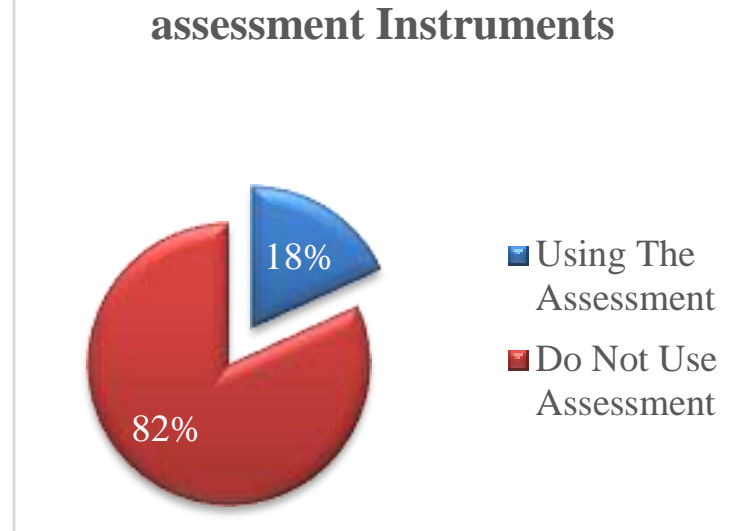

Fig 1. Percentage use of the initial academic assessment instruments

There is still so much demand that is faced by the teachers in the students' academic assessment with intellectual disability, based on the field survey that is done in 11 special schools in Surakarta by interviewing 50 special teachers. Practically, as shown by picture 1, the problem is that the school has not taken a serious action to do an early academic assessment or not doing it all either. In the beginning of the student admission, the school simply group the students based on their age, whether they are 7-8 years old, where in that age is the standard age decided by the government. Besides, the students that are still not able to control themselves and sit calmly are grouped into the below average class and not getting special intervention. The teachers cannot really do the assessment because they have already identified the students from their behavior. Later, the further assessment will be done by 
therapist or psychologist. There are many teachers that do not fully understand the students' ability as a whole and detailed in the beginning of academic year as the purpose of the learning activity itself. This affect to the teachers' intervention that does not fully goes to the purpose of the learning that supposed to be reached by the students and the students' supporting ability so that they will be independent on their own during the learning activity. The implementation of the academic assessment that is not wellarranged in the beginning of the learning activity or even the assessment process that is not held affect to the implementation of assessment process itself. Besides, the teachers' ability to understand the students' condition has an effect to the quality of learning activity at school. Although the assessment's guidance instruments has been made by the government, but the use of it is still limited and has a tendency to be forgotten due to the long time process. The teachers tend to choose the instruments that they develop themselves and have a quick process. That is why the implemented instruments are still simple and the assessment process is not so detailed. As an example, teacher who indicates the basic writing ability will only focus on the letter that is written by the students. If we go deeper, however, the teachers could actually watch on how their students trying to understand the concept of the shape of the letter, the way they hold their pencil, the style of how they sit, and the students' body language when writing. This shows that the teachers are hard to decide what kind of aspect that is right and needed in measuring the students' academic ability for their placement or even for the learning planning.

Teachers tend to less pay attention other aspects non-academically, such as the style of the students in studying or the impact of the intellectual disability that is actually not clearly seen at the very first place but surely could obstruct the students' activity in studying. This becomes very difficult when the teacher could consult it further or do the further assessment with the professionals, such as therapist, psychologist, or medical personnel. As a result, the teachers will find it hard to choose which intervention program that will become the priority in the learning process.

Teachers will likely chase the formality of what has been targeted in the curriculum. This will make the students lost in reaching their basic competence in the curriculum effectively. Besides, the implementation of the education for people with mental illness is likely oriented to the need of the children and the personal approach. It is all simply caused by the need and the ability of every student is different based on the need, problem, and the children's ability.

Teachers are asked to understand and be persistent in assessment academic process. Not only that, they are also asked to be more thorough in paying attention to all the aspects and the activities that have correlation with the goal of the assessment or the expected ability that may appear. The empirical study that has been done shows that $18 \%$ (Picture 1) of teachers have done their assessment early in their learning activity and have a standardized assessment. That standardized assessment is taken from the developing of the school or psychological assessment that includes many aspects, not only the academic ones, but also motor aspect, social emotion, and communication. Even if it is not standardized, in assessing the students, teachers should actually understand their characteristic through personal approach, said by Gargiulo (2012) the general characteristic in learning and behavior are divided into 7, attention, memory, motivation, academic progress in general (knowledge), linguistic development, style of learning, and social development.

The study that has been done shows how the purpose of long and short term assessment, and the function of assessment for students' placement, the selection or diagnostic, not simply become the first 
reference in the learning process. Moreover, teacher will only use their materials in the syllabus and the indicator from the curriculum to teach. It is very rare that they do the assessment at the very first place, because what important to them is the reached competence and the effective indicator in the curriculum.

The assessment that is done by the teacher at school tends to be formative and summative. The formative assessment is done by the teacher after they give the materials to the students as a feedback for the students' learning ability. Different with the formative assessment, the summative one is given to evaluate the program and learning material. This makes the teacher harder to measure the actual potential that the students have and develop the potency that is owned by the students in the future since the teachers do not see the ability and the early obstacle of the students thoroughly. The impact makes the students who are not assessed well is that the academic result that does not show a really good track and teachers only chase for the curriculum reaching, and also the potency's development process that is owned by the students turns too late. Not only that, the way that mostly done by teachers is by doing observation method, because it does not take a long time and is easy to do. However, the bad side of this assessment method is that it does not have a proper judgment structure to measure the students' ability, because the students' condition when being observed can change following the environment atmosphere and will only assess the appeared behavior from the children.

The use of the right assessment instruments, it must be standardized based on the indicator that is also used as the indicator of the ability that must be reached. This indicator that is different in each school depends on the school's agreement and policy. It is caused by many factors that makes the school's policy different, such as there is no exact reference in norm judgment, $18 \%$ of total school use their own reference based on the teachers' experience, $27 \%$ of the total school use the reference that is standardized well, and 55\% of them do not do the early assessment and only do the assessment in the middle or the last of learning activity. This cause an impact to the interpretation of the score or the obstacle that is owned by the students may turn meaningless.

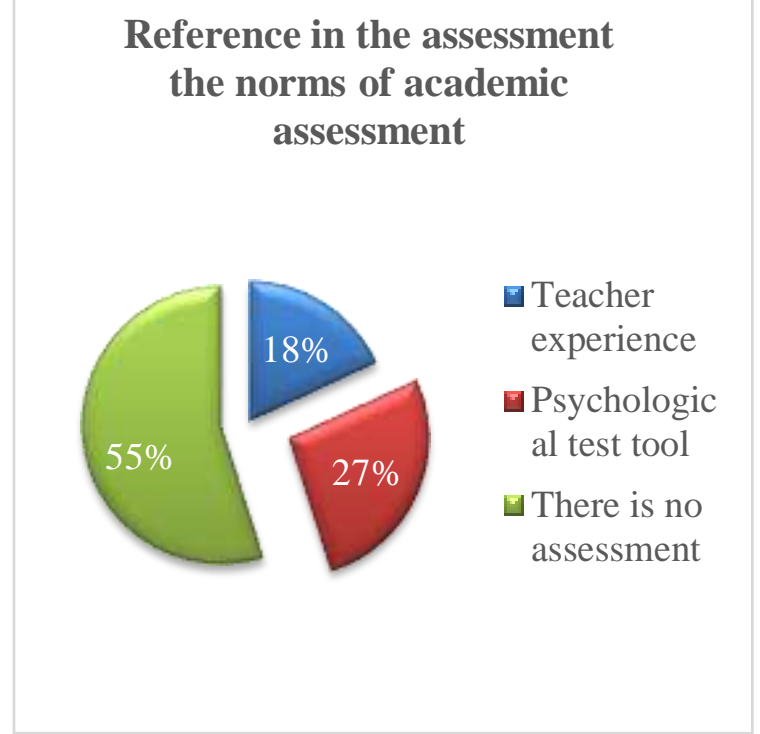

Fig 2. The percentage of the use of the reference norms of academic assessment assessment

The impact of the problem happen when the teachers do the assessment has a possible chance to produce the assessment result that does not accommodate the skill that is will be assessed by the teachers. Maybe the obstacle and potency affect the students' needs that actually could be accommodated and developed by the teachers. Not only that, it can also affect the long and short term purpose or the function of the assessment that would have been done.

Assessment is the tool to gather as much information by the teachers in placing the students, making the individual learning program, or even the plan of classical learning in special schools. The use of simple assessment instrument affects the non-detailed information of the students' condition with mental illness. It is because the teachers have not specifically understood what aspects that they actually need to measure. The aspects that would be measured are only limited to the teachers' understanding about anything that becomes the basic competence target and curriculum, even though 
the aspects that are measured must be based on the need of the students with mental illness. The right implementation of assessment instrument will make teachers and schools easier to learn the students' condition and decide the program that will become the priority in the learning process.

Based on the all the problems above, it shows that the academic assessment instruments for student with mental illness need a development. The development is made to make the teachers easier in doing the students' assessment that has been standardized to measure the academic skill in detail. Not only that, the instrument development that has been rooted firmly is expected to accommodate the teachers and the schools to do the judgment for the students' ability to set the plan of learning program.

\section{Closing Chapter}

The development of assessment instrument more especially in academic field must be well developed comprehensively according to the development of the education for students with mental disability. Besides, the academic assessment development must be followed by the non-academic assessment development since it will help teachers in analyzing the students' ability that is directly affecting to the students' intellectual ability. The most important in an implementation of the assessment is that the quality of the measurement done by the teachers in excavating and developing the students' potency to live independently by their own self.

The development of instruments should not only chase for the materialization of what is targeted inside the curriculum. But, the teachers themselves should have a long and short term plan for the students. The purpose is that to optimize effectively that intervention that is done by teachers at schools. As a result, when the students are not in the school area they will not depend on others and the intervention result will turn to be just a formality of the teaching and learning process at school. Both the students and the teachers should be bold on how the implementation of students with mental illness is always oriented to the need of the students and the service of education itself individually at the very first place.

\section{References}

Bungin M B. (2013). Metodologi Penelitian Sosial Dan Ekonomi: Format-format Kuantitatif dan Kualitatif untuk Studi Sosiologi, Kebijakan, Publik, Komunikasi, Manajemen, dan Pemasaran. Jakarta: Kencana Prenada Media Group.

Hussu MA \& Strle M. (2010). The assessment of children with special needs. Jornal Procedia Social and Behavioral Sciences, Volume 2, Issue 2, 2010, Pages 5281-5284

Kemis \& Rosnawati A. (2013). Pendidikan Anak Berkebutuhan Khusus Tunagrahita. Jakarta: PT. Luxima Metro Media

Silvia J \& Ysseldyke JE. (1995). Assesment Sixth Edition. USA: Houghton Mifflin Company.

Syamsi I. (2016). Pelaksanaan Evaluasi Asesmen Akademik Siswa Tunalaras di SLB-E Prayuwana. Jurnal Pendidikan Khusus, Vol 12, No 1

Thurlow, M. L., Elliott, J. L., \& Ysseldyke, J. E. (1998). Testing Students With Disabilities. California: Corwin Press, Inc

Widoyoko EP. (2012). Teknik Penyusunan Instrumen Penelitian. Yogyakarta: Pustaka Pelajar 